\title{
DIE STAATSTAALDIENS: FUNKSIES EN INVLOED TEN OPSIGTE VAN DIE NORMERING VAN TAALGEBRUIK
}

\author{
D.W. Le Roux
}

$1 \quad$ Inleiding

Die staatstaaldiens se funksie is die vertaling en taalversorging van amptelike publikasies van die staat. Omdat hierdie gublikasies oor 'n wye verskeidenheid onderwerpe handel en deur ' $n$ groot aantal skrywers -.- elk met sy eie idiolek en styl --- saamgestel word, is daar 'n deurlopende behoef te aan normering en standardisering van die taalgebruik in hierdie dokumente.

Deur hierdie normeringsproses oefen dle staatstaaldiens ' $n$ aansienlike invloed op sowel Afrikanse as Engelse taalgebruik uit, nie net in die staatsdiens nie mar ook in wyer kring --- orals waar staatspublikasies deur taalgebruikers gelees word of berigte daaroor in die media hulle bereik.

Daar word dus by implikasie van elke taalpraktisyn in die staatstaaldiens verwag om voortdurend te normeer en te standaardiseer ten opsigte van elke dokument waraan hy werk.

2 Orie sentrale norme vir taalgebruik

Die strewe, by sowel taalversorging as vertaling, is om ' $n$ taalgebruik te handhaaf wat geskik is vir die amptelike publikasies van die Regering en die staat. Hierdie geskiktheid berus op ten minste drie matstawe:

(1) Dit moet duidelike taal wees. Wat gesê word, moet duidelik gesê word sodat daar geen misverstand kan ontstaan nie. ' $n$ Publikasle is per slot van sake bedoel vir kommunikasie. 
http://spilplus.journals.ac.za/

(2) Dit moet "goeie" taal wees, sodat dit nie verleentheid vir die owerheid sal skep nie. Vir doeleindes hiertan word "goeie" taal beskou as algemeen in ooreenstemming met gesaghebbende bronne (woordeboeke, taalhandleidings, ensovoorts).

(3) Dit moet algemeen aanvaacbare taal wees, dit wil sê die opgevoede moedertaalspreker moet dit aanvaarbaar vind.

Probleme

Laasgenoemde twee matstawe bring mee dat die vertaler/redigeerder voortdurend in 'n konfliksituasie verkeer en gedwing word om steeds kompromieë te tref tussen die (soms starre en argaistiese) voorskrifte van woordeboeke en taalhandleidings aan die een kant en die taalgebruik van die opgevoede moedertaalspreker aan die ander kant. Hy word gedurig gekonfronteer met gevalle war die bronne tot sy beskikking 'n bepaalde gebruik voorskryf wat in die moderne spreek- en skrytaal nie meer gangbar is nie. Die vertaler/ redigeerder word dan genoodsaak om hom op sy eie taalgevoel, warneming en cordeel te verlaat en ' $n$ arbitrêre besluit te neem --- heel dikweis in stryd met gesaghebbende taalbronne. Deur so ' $n$ besluit te neem -- hetsy in navolging van of in stryd met die bronne --- stel hy hom bloot aan kritiek van die een of ander kant.

'n Uiterste voorbeeld van sulke argaistiese voorskrifte is war die Tweetalige Woordeboek van Bosman, Van der Merwe en Hiemstra (sewende uitgawe) die woord perait nog as 'n Anglisisme bestempel en die voorkeur gee aan permissiebiljet, vergunning en verlofbrief.

Met die oog op Matstaf 2 (goeie taal) hou die taalpraktisyn soms noodgedwonge ' $n$ skyn van legitimiteit yoor deuc byvoorbeeld (met uitsluiting van ander bronne) te steun op een bron wat ' $n$ bepalde uitdrukking wel aangee -- kortom, die gesaghebbende bronne word selektief gebruik.

Om aan genoemde matstawwe te voldoen, moet die taalpraktisyn soms afwyk van die voorskifte van woordeboeke en boeke oor taal, omdat hierdie bronne nie altyd voorsiening mak vir die probleme warvoor hy daagliks te staan kom nie. 
'n voorbeeld van so ' $n$ voorskrif is die Afrikaanse Woordelys en Spelreëlg (AWS) se bekende gewapendebetoningenieur-reël. Die logika en die (teoretiese) betekenisverskil wat aan:hierdie reël ten grondslag lê, is duidelik, mar in die praktyk word dikwels gevind dat dit onwenslik, moeilik en selfs onmoontlik is om die reël konsekwent toe te pas.

Byvoorbeeld, die uitdrukking plaaslike owerheidsaangeleenthede moet volgens hierdie reël as een woord geskryf word want dit slaan op aangeleenthede rakende plaaslike owerhede en nie op plaaslike aangeleenthede nie, maar daar kan beswaarlik betekenisverwarring ontstaan as dit twee woorde is. Met ewe veel geldigheid kan geargumenteer word dat daar verskeie $t$ ipes owerheidsaangeleenthede is, byvoorbeeld sentrale en provinsiale en plaaslike, en dat dit hier om die "plaaslike" tipe gaan. Afgesien daarvan dat plaslike-owerheidsaangeleenthede en plaaslikeowerheidsaangeleenthede onooglik is en verwarcing en leesprobleme in die hand kan werk, is dit so dat dit feitlik net taalkundiges is (en dan ook nie eers almal nie) wat hierdie reël verstaan en (probeer) toepas of selfs van die bestaan daarvan bewus is.

Hierdie ceël van die AwS bots dus met die maatstaf van "aanvaarbaarheid" en word gevolglik dikwels veronagsaam -- sonder enige reperkussies. Die opgevoede Af rikaanssprekende aanvaar dit (onwetend) so, en self gebruik hy die reël selde of nooit --- sonder dat daar kommunikasieprobleme ontstaan.

Ander voorbeelde is tersiêre onderwysinrigting en Bidrologiese Mavorsingsinstituut.

Die Engelse uitdrukking to deal with lewer soms vertaalprobleme op, en al gee die woordeboeke verskeie moontlike vertalings aan (behandel, aandag gee aan, ensovoorts), bestaan daar tog 'n behoefte aan die neutrale begrip "handel met", byvoorbeeld in gevalle soos die volgende:

"Any person who falls in category A shall be dealt wh in terms of cegulation $23^{n}$.

Die woordeboeke se vertalings pas nie hier nie en daar is gevolglik besluit om handel met te gebruik: "Daar word wet 'n persoon ... gehandel ooreenkomstig regulasie $23^{n}$. Hierdie uitarukking word trouens ook reedg in sekere wet te gebruik. 
Nog ' $n$ wetsuitdrukking is ('n geskil) na arbitrasie verwys. Let spesifiek op die verskil in voorsetsel met ('n geskil) vir arbltrasie na 'n arbiter verwys. Die verwys na-vorm verskyn egter in die wet op Arbeidsverhoudinge, 1956, en word dus algemeen op die mannekragterrein gebruik. Van daar spoel dit oor na ander, meer algemene terreine. Die vorm word ook deur Jansonius se Nieuw Groot Nederlands-Engels Woordenboek aangegee.

'n Woord wat skynbaar net in woordeboekkringe bestaan, is verpolitiek. volgens die Masionale Woordebok beteken dit "bederf deur 'n politieke saak daarvan te mak". Die term wat egter algemeen, ook deur die media, gebruik word, is verpolitiseer (ook politiseer, en depolitiseer), en in ooreenstemming met die matstaf van aanvaarbaarheld word laasgenoemde woord ook deur die staatstaaldiens gebruik. Die gebruik van verpolitlseer word verder gesanksioneer deur Basiese konsepte in die politiek deur H.J. Kotze en.J.J. van wyk (1980).

Nog ' $n$ woord wat gebruik word in ' $n$ betekenis wat (nog) nie deur woordeboeke erken word nie, is uitdrukking. veral by die wysiging van regulasies, byvoorbeeld "Wysig regulasie 12 (2) (a) deur die uitdrukking 'en Adjunkminister' te skrap". In hierdie verband beteken uitdrukking nie segswyge nie, mar word dit as 'n oorkoepelende term beskou wat 'n woord of woorde, leestekens, simbole, afkortings, syfers, ensovoorts kan insluit. Benewens die spesifieke benawing kan ultdrukking dus ook soos volg gebruik word:

.... deur die uitdrukking $\because, 8104$ of" te skrap

.... deur die syfer/uitdrukking $-178 "$ te skrap

.... deur die simbool/uitdrukking " $\mathrm{CO}_{2} \cdot$ in te voeg.

Alternatiewelik kan ultdrukking, ensovoorts bloot weggelat word, byvoorbeeld

.... deur "aeer as $\mathrm{B500}$ - te vervang deur "meer as $\mathrm{R750}$ -

Verskeie uitdrukkings wat tot redelik onlangs nog taboe was, word tans deur die staatstaaldiens anvaar, byvoorbeld die oorganklike gebruik van die werkwoord voorsien, benewens die onoorganklike gebruik (voorsien van/verskaf), byvoorbeeld "Die dam voorsien water aan 'n groot gebied". Trouens, die Departement van Waterwese "verskaf" of "lewer" selde water maar "voorsien" dit dikwels, en ten opsigte van elektrisiteit geld deselfde vir EVKOM, die Elektrisiteitsvoorsieningakommissie. 
Hierdie kantoor aanvaar dus tans die oorganklike gebruik van voorsien, maar hy wak nog teen konstruksies van die tipe "Die dam voorsien die stad". Ook Die korrekte woord (ou en nuwe pitgawe) bepleit die oorganklike gebruik van voorsien, en die jongste uitgawe van die HAT (p. 1312) bevat ook ' $n$ voorbeeldsin met voorsien in hierdie betekenis. (Die vorige uitgawe het dit nie erken nie.)

Normering en die beinvloeding van taalgebruik vind dikwels as gevolg van nie-talige faktore plas, byvoorbeeld om politieke redes. So is ras en Bantoe vervang deur onderskeidelik bevolkingsgroep en swart(e). 'n Belangrike kategorie wat in dié verband genoel kan word, is die geykte formulerings in regulasies, ensovoorts. In hierdie tipe dokument is die taalgebruik in groot mate gestandaardiseer omdat die betrokke taalgebruikshandelinge so herhalend van aard is. Dieselfde uitdrukkings kom by herhaling voor in regulasies, proklamasies en Goewermentskennisgewings, byvoorbeeld "Kragtens die bevoegdheid my verleen by artikel ..." Die inligting wat in hierdie frase vervat is, kan op verskeie ander maniere oorgedra word, mar in die regstaal wat vir die staatskorant gebruik word, is dit die vaste uitdrukking wat reeds dekades lank gebruik word.

Hierdie standaardisasie van die bewoording van regsdokumente bespaar baie tyd en is van groot nut wat die opleiding van juniors betref, omdat hulle dit maklik kan aanleer. Dit geld vir junior beamptes in hierdie kantoor en ook vir juniors in die departemente war hierdie dokumente opgestel word.

Wat die kursivering van tatynse uitdrukkings betref, is die posisle in in mate onvas, maar oor die algemeen word sulke uitdrukkings wel gekursiveer. Veral waar die uitdrukking uit meer as een woord bestaan en in ' $n$ kompositum gebrulk word, is kursivering 'n nuttige manier om aan te dui dat die laaste komponent van die kompositum aan die hele uitdrukking gekoppel word (eenhe idsaanduiding), byvoorbeeld

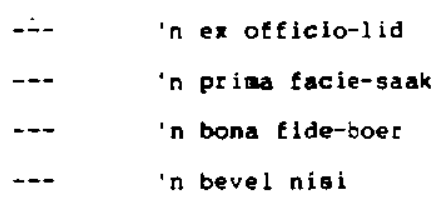


Departement van Gemeenskapsbou, die Landmeter-generaal en die statstaaldiens. Daar is onder meer besluit ompy die volgende patrone te hou:

-.- "Begin by baken A; daarvandaan weswaarts ....", en nie "Vanaf baken A; dan weswarts ...."nie, want dit gaan hier in die eerste plek om plek en nie tyd nie.

-. "... sodat die eiendom by hierdie gebied ingesluit word ..." (nie in nie).

-... in "n reguit lyn tot by ..." ("nie "reguit tot by" nie).

Daar word dikwels gesê dat "Staatsdienstaal" te vaag en omslagtig is en byvoorbeeld wemel van uitdrukkings soos ten opsigte van. Dit gebeur egter dikwels dat ' $n$ amptelike stuk doelbewus vaag bewoord word om ' $n$ bepalde effek te verkry. Byvoorbeeld, in die sin "Pensioene word ten opsigte van mynwerkers betal" sou die voorsetsel aan nie deug nie omdat pensioene in die onderhawige geval nie net aan die mynwerker self betaal word nie maar ook aan sy nasbestaandes indien hy reeds oorlede is.

4 Slot

Die taal in staatspublikasies kan as "korcekte", "goeie", "standaard"taal beskou word. Dit is nie tendensieus nie mar trag net om inligting so helder en duidelik as moontlik oor te dra. Die "status" van hierdie taalgebruik blyk daarit dat die waT telkens voorbeeldsinne uit statspublikasies haal.

Die tekste wat die staatstaaldiens vertaal en redigeer, wissel van die uiters formele styl en geykte frases van die regstal tot die relatief informele styl van byvoorbeeld populêt-wetenskaplike pamflette oor gesondheidsaangeleenthede, en ook die vryer mar steeds wardige styl van toesprake vir die statspresident en Ministers en verslae van kommissies van ondersoek. In al hierdie gevalle moet die vertaler/redigeerder egter --met inagneming yan die leserspubliek of gehoor vir wie die betrokke stuk bedoel is --- telkens besluit of 'n spesifieke woord of uitdrukking geskik is binne die bepalde verband. Hier moet hy hom.telkens laat lei deur die drie matstawe van duidelike taal, goeie taal en algemeen aanvaabare taal. 


\title{
BIBLIOGRAFIE
}

\author{
Bosman, D.B., I.W. Van der Merwe, \& L.W. Hiemstra (1967) Tweetallge woorde- \\ boek. Sewende Uitgawe. Kaapstad: Tafelberg. \\ De Villiers, M., J. Smuts, \& L.C. Eksteen (1971) Nasionale woordeboek. \\ Kaapstad: Nasou. \\ Jansonius, H. (1972-1973) Nieuw groot Nederlands-Engels Woordenboek voor \\ studie en praktijk. Leiden: Nederlandsche Uitgeversmatschappij. \\ Kotze, H.J. J J.J. van Wyk (1980) Baslese konsepte in dle politiek. \\ Johannesburg: MCGraw-Hill. \\ Odendal, F.F. (red.) (1979) Verklarende handwoordeboek van die Afrikaanse \\ taal. Johannesburg: Perskor. \\ Van der Merwe, H.J.J.M. (1968) Die korrekte woord. Vyfde, hersiene en \\ uitgebreide druk. Pretoria: Van Schaik.
}

